ISSN 1392-3196 / e-ISSN 2335-8947

Zemdirbyste-Agriculture, vol. 108, No. 2 (2021), p. 99-108

DOI 10.13080/z-a.2021.108.013

\title{
Effects of winter wheat roots on recovery of bulk density, penetration resistance and water-stable aggregation of sandy loam Eutric Cambisol and clayey loam Vertic Cambisol after compaction
}

\author{
Eugene BALASHOV ${ }^{1}$, Sergio PELLEGRINI ${ }^{2}$, Paolo BAZZOFFI ${ }^{2}$ \\ ${ }^{1}$ Agrophysical Research Institute \\ Grazhdansky prospekt 14, 195220 St. Petersburg, Russia \\ E-mail: Eugene_Balashov@mail.ru \\ ${ }^{2}$ Council for Agricultural Research and Economics - Agriculture and Environment (CREA-AA) \\ 12/a Via Lanciola, 50125 Firenze, Italy
}

\begin{abstract}
The objectives of the experiment were to: (1) evaluate the effects of ground contact pressures of $0.051,0.103$ and $0.154 \mathrm{MPa}$ on physical properties of sandy loam Eutric Cambisol and clayey loam Vertic Cambisol, and (2) assess the effects of winter wheat roots on the recovery of physical properties of the compacted soils. A 49day pot experiment included treatments with winter wheat (Triticum aestivum L.) growing until the $\mathrm{BBCH} 10$ growth stage. The ground contact pressures were created by a hand-operated hydraulic compressor equipped with a manometer. As a reference, pots with uncompacted soils without plants were also included in the experiment. At the end of the experiment, bulk density, penetration resistance, total amount of water-stable aggregates (WSA), their size fractions and weight of dry roots in the whole $0-15 \mathrm{~cm}$ layers of both soils were determined.

The ground contact pressures resulted in significantly higher mean values of bulk density in the $0-15 \mathrm{~cm}$ layers for both soils without plants compared to the uncompacted soils. Winter wheat roots contributed to a decrease in the mean values of bulk density of the clayey loam by $1.4,3.8$ and $4.9 \%$, but caused the increase in those of the sandy loam by $6.2,5.1$ and $1.8 \%$ at the ground contact pressures of $0.051,0.103$ and $0.154 \mathrm{MPa}$, respectively. The ground contact pressures caused mostly a significant increase in the mean penetration resistance of the $0-5 \mathrm{~cm}$ layer in the clayey loam and sandy loam without plants compared to the uncompacted soils. The roots did not contribute to any significant change in the mean magnitudes of penetration resistance of both soils at the three studied levels of compaction. Total amount of WSA of the two soils significantly decreased after the compaction by all the applied ground contact pressures. Winter wheat roots contributed mainly to a partial recovery of the total amount of WSA in both compacted soils compared to those of the uncompacted soils.
\end{abstract}

Key words: soil, compaction, soil bulk density, penetration resistance, water-stable aggregation, recovery, winter wheat roots.

\section{Introduction}

Currently, soil compaction is still one of the main factors of deterioration of soil physical state Soil compaction leads to an increase of bulk density and penetration resistance and to a decrease of water-stable aggregation (Batey, 2009; de Moraes et al., 2020; Ferreira et al., 2020; Rizaldi et al., 2020). These unfavourable consequences of soil compaction led to a decrease in soil porosity and aeration, water-filled pore space, amounts of available water, rates of water movement, root growth and nutrients (Mujdeci et al., 2017; Hargreaves et al., 2019; Seehusen et al., 2019). The capacity of soils to recover from such anthropogenic impacts depends on their properties, such as texture, soil organic matter, and their consequent effects on soil structure (Arthur et al., 2012).

Among the factors of recovery (tillage and plant residues) of compacted soils plant roots can also play a useful role. Soil aggregate stability, penetration resistance and bulk density are important parameters for assessing soil physical state after different impacts (Steponavičienè et al., 2020). Roots demonstrate a favourable influence on soil porosity, bulk density and water-stable aggregation (Bodner et al., 2014; Vergani,

Please use the following format when citing the article:

Balashov E., Pellegrini S., Bazzoffi P. 2021. Effects of winter wheat roots on recovery of bulk density, penetration resistance and water-stable aggregation of sandy loam Eutric Cambisol and clayey loam Vertic Cambisol after compaction. ZemdirbysteAgriculture, 108 (2): 99-108. DOI 10.13080/z-a.2021.108.013 
Graf, 2016; Stumpf et al, 2018; Vezzani et al., 2018). Helliwell et al. (2019) reported that across the three plant species (pea, tomato and wheat) significant increases in porosity at the immediate root surface were found in clay loam and loamy sand at a bulk density of 1.2 and $1.5 \mathrm{Mg} \mathrm{m}^{-3}$. According to Oleghe et al. (2017), plant root exudates influence the root growth pressure and porosity of the surrounding soil. The authors reported that after compression tests of $200 \mathrm{kPa}$ the increase in volume of seed exudate from Salvia hispanica from 0 to $1.85 \mathrm{mg} \mathrm{g}^{-1}$ penetration resistance decreased by $77 \%$ for the sandy loam Dystric Cambisol and by $36 \%$ for the clay loam Gleyic Cambisol demonstrating that exudates easily penetrate into compacted soils. Koebernick et al. (2019) also reported that the presence of hairless barley (Hordeum vulgare L.) roots increased the total detectable pore volume and narrowed the pore size distribution in a sandy loam Dystric Cambisol. They also reported that the presence of hairs on barley roots is more likely to affect inter-aggregate pore structure.

Roots, fungal and microbial biomass, polygalacturonic acids, labile polysaccharides, hydrophobic aliphatics, particulate organic matter and microbialderived mucilages are included in well-known hierarchical models of micro- and macroaggregate formation mechanisms (Six et al., 2002; 2004). Denef and Six (2005) reported that the presence of actively growing winter wheat roots significantly stimulated microbial activity and simultaneously promoted the formation of large macroaggregates of illitic loam Haplic Kastanazem after 46 days of winter wheat at $\mathrm{BBCH} 10$ growth stage (or Feekes 10.0 boot stage) in 1 litre pots with $850 \mathrm{~g}$ of soil at the field capacity. Carrizo et al. (2015) showed that growing of winter wheat on loamy Typic Hapludoll and silty Typic Argiudoll contributed to increasing content of particulate organic matter, carbohydrates, proteins and, as a result, to improving soil aggregate formation and stabilization.

The ability of plant roots to recover the aggregates of damaged soils is dependent on many factors: plant species, their root length density, specific root length, root morphology, soil bulk density, soil macroporosity, soil penetration resistance, soil texture and mineralogy, soil moisture content, microbial activity and organic carbon content (Martins et al., 2009; Chimungu et al., 2015; Gould et al., 2016; Koebernick et al., 2017; Vezzani et al., 2018; Atkinson et al., 2020; de Moraes et al., 2020).

The root-induced recovery of soil bulk density, penetration resistance and water-stable aggregation after compaction are affected by magnitudes of applied ground contact pressures of tractors and harvesters. An ability of root to grow in the compacted soils is induced by penetration resistance and macroporosity (Atkinson et al., 2020). According to Clark et al. (2003), maximum axial winter wheat root growth pressure is $0.49 \mathrm{MPa}$. However, a strong limitation of root growth in soils is usually observed at penetration resistance of $2-2.5 \mathrm{MPa}$ resulting in the formation of high volume of soil micropores, which can be smaller in diameter than the roots (Carrara et al., 2007).

At the time of the experiment described in this paper, the area under winter wheat in Central Italy was about $20 \%$ of the total crop area (Bianchi, 1995). The growing of winter wheat demands an application of machinery (tractors and harvesters), and its development over the last few decades has introduced machines of a greater weight and has increased the problems of finding tyres and ground contact pressures, which are capable of keeping soil compaction low by different tools (Pagliai et al., 2003). One of the possible tools can be the maintenance of optimal soil physical state by roots of growing winter wheat.

The objectives of the experiment were to: (1) evaluate the effect of the ground contact pressures of 0.051 , 0.103 and $0.154 \mathrm{MPa}$ on physical properties of sandy loam Eutric Cambisol and clayey loam Vertic Cambisol, and (2) assess the effect of winter wheat roots on the recovery of physical properties of the compacted soils.

\section{Materials and methods}

Soils were classified as sandy loam Eutric Cambisol and clayey loam Vertic Cambisol (WRB, 2014). Disturbed field moist soil samples for the laboratory experiment were collected from the upper 0-20 cm layer of plots with winter wheat (Triticum aestivum L., 'Pandas') at the Fagna $\left(43^{\circ} 59^{\prime} \mathrm{N}, 11^{\circ} 20^{\prime} \mathrm{E}\right)$ and Vicarello $\left(43^{\circ} 27^{\prime} \mathrm{N}\right.$, $11^{\circ} 30^{\prime}$ E) Research Stations of the Experimental Institute for Soil Survey and Conservation, Florence, Italy. The sandy loam contained $44 \%$ of sand $(53-2000 \mu \mathrm{m}), 40 \%$ of silt $(2-53 \mu \mathrm{m}), 16 \%$ of clay $(<2 \mu \mathrm{m}), 6 \%$ of total $\mathrm{CaCO}_{3}, 1.0 \%$ of total organic carbon and had a $\mathrm{pH}$ value of 7.8 (Valboa et al., 2015). The clayey loam contained $15 \%$ of sand, $43 \%$ of silt, $42 \%$ of clay, $12.8 \%$ of total $\mathrm{CaCO}_{3}, 0.5 \%$ of total organic matter and had a $\mathrm{pH}$ value of 8.2 (Torri et al., 1999).

The soil material without roots of winter wheat was air-dried, passed through a $2 \mathrm{~cm}$ sieve and then moistened to a field capacity, which was equal to $20 \%$ (of weight) in sandy loam and $27 \%$ (of weight) in clayey loam. Experimental cylindrical PVC pots had a volume of $1440 \mathrm{~cm}^{3}(9.7 \mathrm{~cm}$ in diameter and $19.5 \mathrm{~cm}$ high). The soil surface area in the pots was $73.86 \mathrm{~cm}^{2}$. The soil material was placed into the pots at the bulk density of $1.16 \pm 0.01 \mathrm{Mg} \mathrm{m}^{-3}$ for sandy loam and $1.15 \pm$ $0.01 \mathrm{Mg} \mathrm{m}^{-3}$ for clayey loam. These values of equilibrium soil bulk densities were determined at the time of the field soil sampling and were considered as initial bulk density. The soil in the cylinders was compacted with the ground contact pressures of $0.051,0.103$ and $0.154 \mathrm{MPa}$ by using a hand-operated hydraulic compressor equipped with a manometer to measure the compressive force of the steel compression piston on the soil surface. A contact area of the steel compression piston was $71.44 \mathrm{~cm}^{2}$. The selected ground contact pressures are in the ranges of conventional pressures of tractors or harvesters on soils (Holthusen et al., 2018).

The laboratory experiment included compacted soils with and without winter wheat plants was conducted in three replicates; there were $18 / 18$ pots without/with winter wheat for each soil. The winter wheat plants were grown for 49 days, which was necessary to reach the beginning of the BBCH 10 growth stage (or Feekes 10.0 boot stage). This growth stage of winter wheat was chosen to allow the maximum root growth and root production (Denef, Six, 2005). As a reference, three pots were kept with each uncompacted soil without growing of winter wheat during the entire period of the experiment. It was assumed that growing of winter wheat in the reference pots could cause soil compaction by winter wheat roots (Chomczyńska et al., 2016) and, as a possible result, a disturbance of water-stable aggregates (WSA).

The pots without winter wheat and with seedlings of winter wheat plants just after germination 
were placed on a roof of the Experimental Institute building at spring-summer (April-June) weather conditions in Florence, Italy. In our previous experiment (Balashov, Bazzoffi, 2003), the soil moisture content was maintained by adding water regularly but only from above the soil to maintain the field capacity during a whole period of the research. In the present experiment, all the pots were placed in trays with water of $2.5 \pm$ $0.5 \mathrm{~cm}$ deep to maintain a constant flow of water into the soils from below. It was supposed that the constant flow of water from below would contribute to a greater density and length of roots and their better development. The pots were regularly weighed, and the soils were also moistened from above to maintain the average values of moisture content for both soils slightly higher than their field capacity.

A height of soil in the pots was $19 \mathrm{~cm}$. The penetration resistance and amount of WSA were measured in the top $15 \mathrm{~cm}$ of the column. At the end of the pot experiment, composite samples of soil $(400 \mathrm{~g})$ for each treatment were collected from $0-5,6-10$ and $11-15 \mathrm{~cm}$ layers of the column. To determine the amount and distribution of the dry aggregates size fractions, the samples were air-dried and sieved through a set of sieves with mesh diameters of $0.25,0.5,1.0,2.8,5.66$ and $9.51 \mathrm{~mm}$.

To measure the amount and distribution of WSA size fractions, the dry aggregates of each treatment were composed into $50 \mathrm{~g}$ samples (according to the content of each size fraction). The measurements were conducted in three replicates, and the wet sieving method was used with a set of sieves with mesh diameters of $0.25,0.5,1.0,2.8$, 5.66 and $9.51 \mathrm{~mm}$. The samples of dry aggregates were capillary saturated by water for $10 \mathrm{~min}$, placed on the top of the set of sieves, immersed directly into water in an apparatus for vertical oscillation and were mechanically oscillated with a stroke of $40 \mathrm{~mm}$ and at a frequency of 30 cycles $\mathrm{min}^{-1}$ for $10 \mathrm{~min}$ (Valboa et al., 2015).

Size fractions of WSA were collected from each sieve and oven dried at $40^{\circ} \mathrm{C}$ temperature. Weight of each size fraction corrected for sand content was expressed as a percentage of the total amount of WSA. At the end of the pot experiment, contents of different size fractions of WSA were also measured in the uncompacted (reference) soils (Valboa et al., 2015). The soil penetration resistance in each of the pots was measured by an Eijkelkamp penetrometer (06.15.SA) with a cone diameter of $1.6 \mathrm{~cm}$, cone angle of $60^{\circ}$ and average penetration speed of $2 \mathrm{~cm} \mathrm{~s}^{-1}$ (Pagliai et al., 2003). The measurements were conducted in three replicates for each pot

All the soil columns were carefully removed from the pots and were divided into three layers of $0-5$, $6-10$ and $11-15 \mathrm{~cm}$. The diameters of these separate soil layers were measured to calculate the bulk density. Samples were taken from the separate soil layers to measure moisture content by a gravimetric method (oven drying at $105^{\circ} \mathrm{C}$ ). Two columns were used to measure weight of dry roots, but weight of dry shoots was determined for all the three soil columns. The roots were separated from the soil by their floating in running water with a subsequent oven drying at $40^{\circ} \mathrm{C}$, and weight of dry shoots was also determined by oven drying at $40^{\circ} \mathrm{C}$.

Strength of associations between sets of soil parameters in all the treatments was assessed with Pearson correlation coefficient $(p \leq 0.05)$. The standard deviations from the mean and the $95 \%$ confidence intervals for the mean were calculated using the Excel. One-way analysis of variance (ANOVA) was applied to evaluate the significance of differences $(p \leq 0.05)$ between the means of the experimental data.

\section{Results and discussion}

Effects of compaction on the soil bulk density. At the end of the experiment, the mean value of the reference bulk density of sandy loam was $1.23 \pm$ $0.02 \mathrm{Mg} \mathrm{m}^{-3}$. At the ground contact pressures of 0.051 , 0.103 and $0.154 \mathrm{MPa}$, mean values of the bulk density of the sandy loam reached $1.44 \pm 0.11,1.55 \pm 0.09$ and 1.66 $\pm 0.11 \mathrm{Mg} \mathrm{m}^{-3}$ (without plants) and $1.54 \pm 0.18,1.64 \pm$ 0.12 and $1.69 \pm 0.06 \mathrm{Mg} \mathrm{m}^{-3}$ (with plants), respectively. The results of one-way ANOVA showed that in the treatments without plants the mean values of bulk density of sandy loam were significantly higher than its reference bulk density, respectively, at the ground contact pressure of $0.051 \mathrm{MPa}(p<0.05), 0.103 \mathrm{MPa}(p<0.01)$ and $0.154 \mathrm{MPa}(p<0.01)$. In the treatments with plants, the mean values of bulk density of compacted sandy loam were also significantly higher than the reference bulk density at the ground contact pressure of $0.051 \mathrm{MPa}(p<0.05)$, $0.103 \mathrm{MPa}(p<0.001)$ and $0.154 \mathrm{MPa}(p<0.001)$.

Significant differences $(p<0.01)$ in the mean values of bulk density between the compacted sandy loam were observed only for the ground contact pressures of 0.051 and $0.154 \mathrm{MPa}$ in the treatments without plants. Roots contributed to an increase in the bulk density of the sandy loam by $6.2,5.1$ and $1.8 \%$ at the ground contact pressures of $0.051,0.103$ and 0.154 $\mathrm{MPa}$, respectively. These results are in accordance with the data of Koebernick et al. (2019), who reported that barley roots induced compression of sandy loam Dystric Cambisol and decreased air-filled pore space between 0.1 and $0.8 \mathrm{~mm}$ from the root surface. Results of our previous experiment (Balashov, Bazzoffi, 2003) showed that the ground contact pressures of $0.051,0.103$ and $0.154 \mathrm{MPa}$ in the sandy loam (with plants) resulted in bulk densities of $1.56,1.71$ and $1.74 \mathrm{Mg} \mathrm{m}^{-3}$, respectively, whereas the bulk density of the uncompacted soil was $1.44 \mathrm{Mg} \mathrm{m}^{-3}$.

At the end of the experiment, a mean value of the bulk density of the uncompacted clayey loam was equal to $1.24 \pm 0.02 \mathrm{Mg} \mathrm{m}^{-3}$. At the ground contact pressures of $0.051,0.103$ and $0.154 \mathrm{MPa}$, the mean values of the bulk density of the clayey loam were equal to $1.40 \pm$ $0.16,1.57 \pm 0.16$ and $1.62 \pm 0.15 \mathrm{Mg} \mathrm{m}^{-3}$ (without plants) and $1.39 \pm 0.13,1.51 \pm 0.11$ and $1.56 \pm 0.15 \mathrm{Mg} \mathrm{m}^{-3}$ (with plants). The results of one-way ANOVA analysis of variance showed that in the treatments without plants the mean values of bulk density of clayey loam were significantly higher than its reference bulk density at two ground contact pressures of $0.103 \mathrm{MPa}(p<0.05)$ and $0.154 \mathrm{MPa}(p<0.01)$. In the treatments with plants, the mean values of bulk density of compacted clayey loam were also significantly higher than the reference bulk density also at two ground contact pressures $0.103 \mathrm{MPa}$ $(p<0.05)$ and $0.154 \mathrm{MPa}(p<0.05)$.

Significant difference $(p<0.05)$ in the mean values of bulk density between the compacted clayey loam was also found only for the ground contact pressures of 0.051 and $0.154 \mathrm{MPa}$ in the treatment without plants. However, the mean values of the bulk density of clayey loam in the treatments with plants tended to be lower than those without plants. Roots contributed to the recovery of the bulk density by $1.4,3.8$ and $4.9 \%$ at the ground contact pressures of $0.051,0.103$ and $0.154 \mathrm{MPa}$, respectively. Results of our previous experiment (Balashov, Bazzoffi, 
2003) demonstrated that the ground contact pressures of $0.051,0.103$ and $0.154 \mathrm{MPa}$ resulted in the values of clayey loam bulk densities of $1.41,1.50$ and $1.56 \mathrm{Mg} \mathrm{m}^{-3}$ (with plants), respectively, whereas the bulk density of the uncompacted soil was $1.30 \mathrm{Mg} \mathrm{m}^{-3}$.

Helliwell et al. (2019) reported that winter wheat roots contributed to a significant increase in porosity at the immediate root surface in clay loam and loamy sand at bulk density of $1.5 \mathrm{Mg} \mathrm{m}^{-3}$. According to these authors, the zone of influence of roots on soil porosity was significantly impacted by species in the following order: winter wheat $\left(694.7 \mathrm{~mm}^{3}\right)>$ pea $\left(483.9 \mathrm{~mm}^{3}\right)>$ tomato $\left(21.2 \mathrm{~mm}^{3}\right)$. Besides, this zone of influence was higher in clay loam than in loamy sand. These data probably can explain the above-mentioned differences in the effects of winter wheat roots on bulk density of sandy loam and clayey loam.

Effects of compaction on depth distribution of the penetration resistance and moisture content in sandy loam. Clark et al. (2003) reported that maximum axial root growth pressure can range from 0.60 to $0.80 \mathrm{MPa}$, while a strong limitation of root growth in soils is usually observed at penetration resistance of 2-2.5 MPa resulting in the formation of high volume of soil micropores (Carrara et al., 2007).

Depth distribution of penetration resistance of the sandy loam in the treatments without and with winter wheat plants is represented in Figure 1.
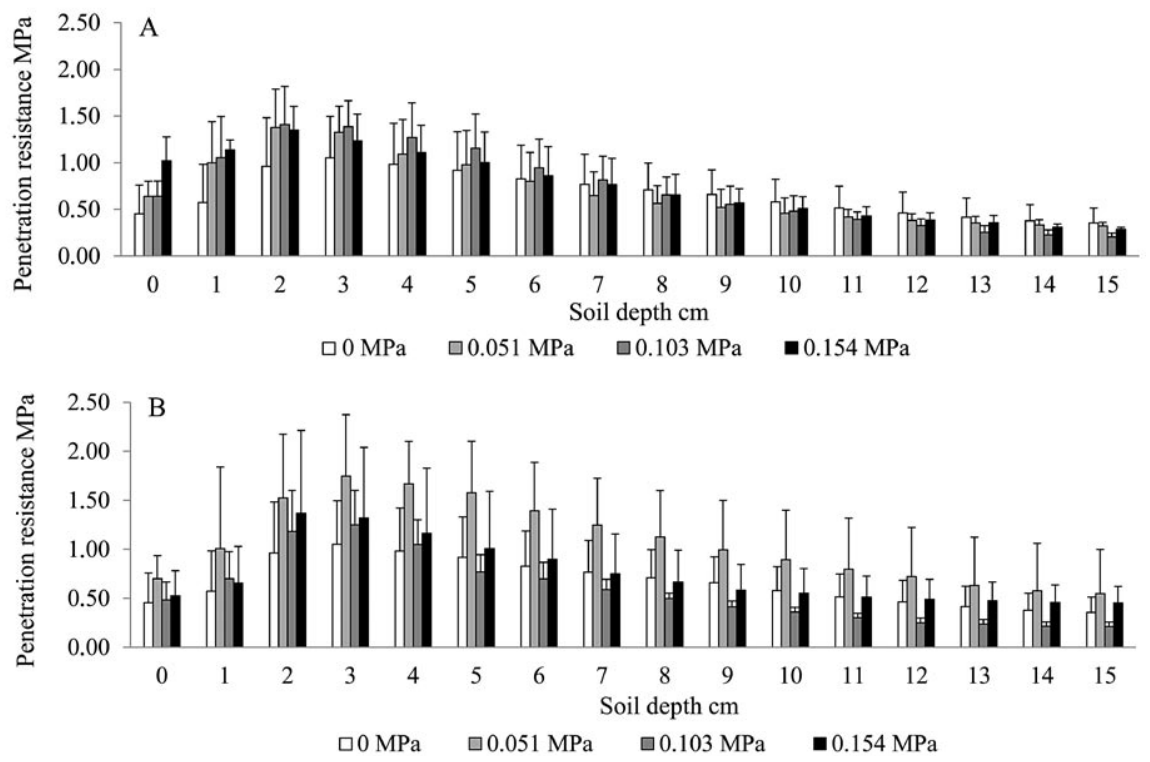

Note. Bars show the $95 \%$ confidence intervals for the means.

Figure 1. The penetration resistance in the $0-15 \mathrm{~cm}$ layer of sandy loam at the ground contact pressures of $0,0.051$, 0.103 and $0.154 \mathrm{MPa}$ without (A) and with (B) winter wheat

In the treatments without plants, the ground contact pressures of 0.103 and $0.154 \mathrm{MPa}$ resulted in significantly higher $(p<0.05)$ average values of penetration resistance $(1.15 \pm 0.28$ and $1.14 \pm 0.13 \mathrm{MPa}$, respectively) compared to the uncompacted soil $(0.82$ $\pm 0.25 \mathrm{MPa})$, but only in the $0-5 \mathrm{~cm}$ layer. The ground contact pressure of $0.051 \mathrm{MPa}$ did not cause a significant increase in penetration resistance $(1.07 \pm 0.28 \mathrm{MPa})$ in the 0-5 cm layer compared to the uncompacted soil. In the 610 and $11-15 \mathrm{~cm}$ soil layers, the differences in penetration resistance were insignificant for all the three studied levels of compaction compared to the uncompacted soil (Figure 1A). The highest values of penetration resistance in the compacted soil were observed at the depth of $2 \mathrm{~cm}$ and were equal to $1.38 \pm 0.38,1.41 \pm 0.41$ and $1.35 \pm$ $0.25 \mathrm{MPa}$ at the ground contact pressures of $0.051,0.103$ and $0.154 \mathrm{MPa}$, respectively.

For the whole $0-15 \mathrm{~cm}$ columns without plants, the ground contact pressures of $0.051,0.103$ and $0.154 \mathrm{MPa}$ resulted only in a slight increase of the mean penetration resistance $(0.70 \pm 0.35,0.73 \pm 0.42$ and $0.75 \pm 0.36 \mathrm{MPa}$, respectively), and the increase was not significant compared to the uncompacted soil with the mean penetration resistance of $0.66 \pm 0.23 \mathrm{MPa}$.

In the treatments with plants, the $0-5 \mathrm{~cm}$ soil layer was also the most sensitive to the effect of the three applied ground contact pressures (Figure 1B).
Nevertheless, only the ground contact pressure of 0.051 MPa led to significantly higher $(p<0.01)$ average values of penetration resistance $(1.37 \pm 0.42 \mathrm{MPa})$ compared to the uncompacted soil $(0.82 \pm 0.25 \mathrm{MPa})$. The ground contact pressures of 0.103 and $0.154 \mathrm{MPa}$ resulted in an increase of the mean penetration resistance in the 0 $5 \mathrm{~cm}$ soil layer up to $0.91 \pm 0.30$ and $1.01 \pm 0.35 \mathrm{MPa}$, respectively, but the differences were not significant compared to the uncompacted soil. The highest values of penetration resistance for this treatment were observed at the depth of $3 \mathrm{~cm}$ and were equal to $1.75 \pm 0.63$ and $1.25 \pm 0.35 \mathrm{MPa}$ at the ground contact pressures of 0.051 and $0.103 \mathrm{MPa}$, respectively. The highest penetration resistance of $1.37 \pm 0.85 \mathrm{MPa}$ at the ground contact pressure of $0.154 \mathrm{MPa}$ was observed at the soil depth of $2 \mathrm{~cm}$. For some replicates penetration resistance of the soil at the depths of 2 and $3 \mathrm{~cm}$ exceeded the critical value of $2 \mathrm{MPa}$. In the $6-10$ and $11-15 \mathrm{~cm}$ layers, the ground contact pressure of $0.051 \mathrm{MPa}$ also resulted in the significantly higher $(p<0.01)$ average values of penetration resistance $(1.13 \pm 0.20$ and $0.65 \pm 0.10 \mathrm{MPa}$, respectively) compared to the uncompacted soil $(0.71$ \pm 0.10 and $0.42 \pm 0.06 \mathrm{MPa}$, respectively). There were no significant effects of the ground contact pressures of 0.103 and $0.154 \mathrm{MPa}$ on penetration resistance in the 6-10 and 11-15 cm layers compared to the uncompacted soil in the same layers. 
In the whole $0-15 \mathrm{~cm}$ columns of the soil with plants, the mean values of penetration resistance were equal to $1.07 \pm 0.41,0.58 \pm 0.34$ and $0.74 \pm 0.31 \mathrm{MPa}$ at the ground contact pressures of $0.051,0.103$ and $0.154 \mathrm{MPa}$, respectively. In general, roots of winter wheat did not contribute to a significant recovery of penetration resistance at the three studied levels of compaction. Nevertheless, the weight of dry roots in the soil decreased with the increasing ground contact pressures and was $1.11 \pm 0.74 \mathrm{~g}$ for the $0.051 \mathrm{MPa}, 0.84 \pm 0.51 \mathrm{~g}$ for the $0.103 \mathrm{MPa}$ and $0.44 \pm 0.13 \mathrm{~g}$ for the $0.154 \mathrm{MPa}$. Chomczyńska et al. (2016) showed that root system of orchard grass contributed to the formation of a specific mesh that bound sand particles and, therefore, the rooted media had a greater penetration resistance. Chalise et al. (2019) reported that penetration resistance of silty loam at a depth of $0-5 \mathrm{~cm}$ was significantly higher on plots with $(2.76 \mathrm{MPa})$ than without (2.24 MPa) a cover crop. As an additional source of higher friction with the penetrometer cone, the presence of dense root system could contribute to the greater increase of penetration resistance at the $0.051 \mathrm{MPa}$ compared to the other ones.

Soil moisture content could be a key factor of any changes in the depth distribution of penetration resistance. However, moisture content of the uncompacted soil was equal to $31.7,28.5$ and $29.6 \%$ in the $0-5,6-10$ and $11-15$ $\mathrm{cm}$ layers, respectively, and had a weak correlation with penetration resistance. In the treatments without and with winter wheat growing on the compacted soils, penetration resistance decreased with the increasing moisture content from $0-5$ to $11-15 \mathrm{~cm}$ layer. In the treatments without plants, moisture content in the $0-5,6-10$ and $11-15 \mathrm{~cm}$ soil layers were changing in the ranges of 14.6-31.5, $15.8-28.9$ and $16.0-26.3 \%$ (of weight), respectively, for all the applied ground contact pressures. The Pearson correlation coefficients for the relationships between penetration resistance and moisture content in the $0-5$, $6-10$ and $11-15 \mathrm{~cm}$ soil layers were $-0.97,-0.99$ and -0.99 , respectively. In the treatments with plants, moisture content in the $0-5,6-10$ and $11-15 \mathrm{~cm}$ soil layers was changing in the ranges of 14.7-26.8, 19.1-25.9 and 19.0 $24.1 \%$ (of weight), respectively, for all the applied ground contact pressures. The Pearson correlation coefficients for the relationships between penetration resistance and moisture content in the $0-5,6-11$ and $11-15 \mathrm{~cm}$ soil layers were equal to $-0.99,-0.85$ and -0.80 , respectively. The penetration resistance decreases with the increasing moisture content as a result of decreasing friction between the penetrometer cone and the soil particles (Bengough et al., 2011; Bartzen et al., 2019).

Effects of compaction on depth distribution of the penetration resistance and moisture content in clayley loam. Depth distribution of penetration resistance was different within the $0-15 \mathrm{~cm}$ soil layer of the compacted clayey loam without and with winter wheat plants (Figure 2).

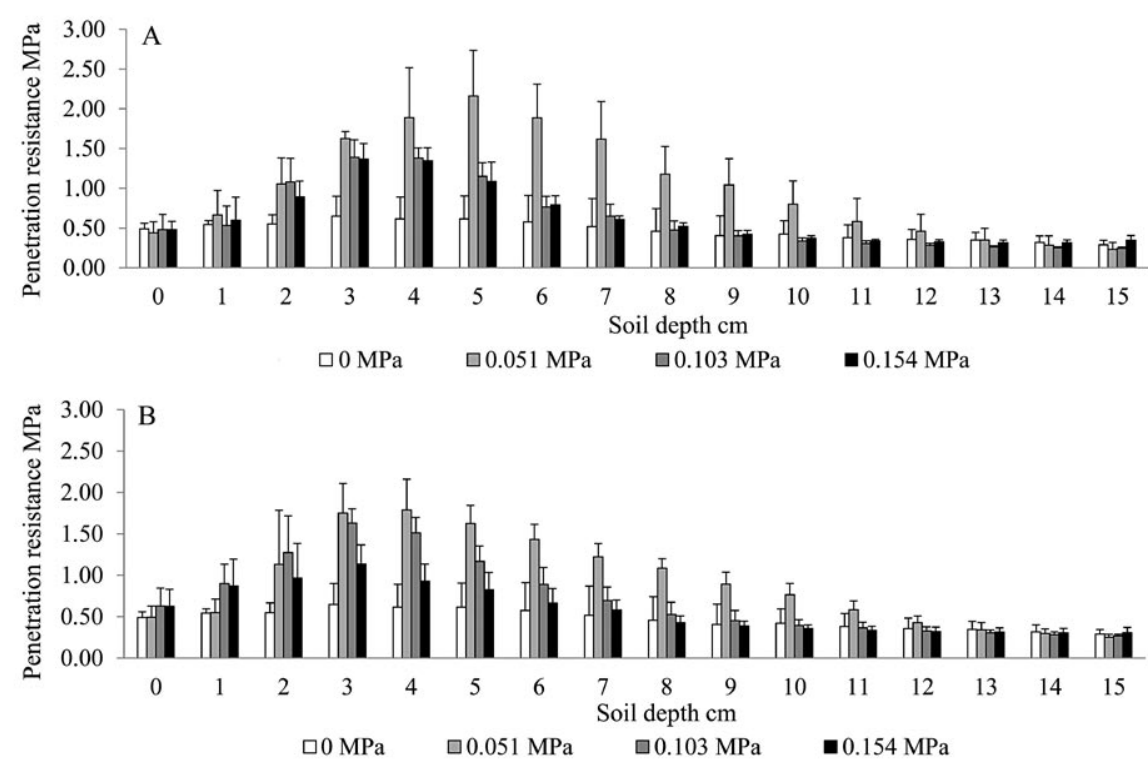

Note. Bars show the $95 \%$ confidence intervals for the means.

Figure 2. The penetration resistance in the $0-15 \mathrm{~cm}$ layer of clayey loam at the ground contact pressures of $0,0.051$, 0.103 and $0.154 \mathrm{MPa}$ without $(\mathrm{A})$ and with $(\mathrm{B})$ winter wheat

In the treatments without plants, the $0-5 \mathrm{~cm}$ layer was also the most sensitive to the impact of the ground contact pressure. There were significant differences $(p<0.05)$ between the average values of penetration resistance of this layer of the uncompacted soil $(0.58 \pm$ $0.06 \mathrm{MPa}$ ) and the soil compacted by the ground contact pressures of $0.051(1.31 \pm 0.69 \mathrm{MPa}), 0.103(1.00 \pm$ $0.40 \mathrm{MPa})$ and $0.154(0.96 \pm 0.37 \mathrm{MPa}) \mathrm{MPa}$. The highest penetration resistance $(2.16 \pm 0.57 \mathrm{MPa})$ of the soil layer was observed at the depth of $5 \mathrm{~cm}$ at the ground contact pressure of $0.051 \mathrm{MPa}$ (Figure 2A). The same ground contact pressure resulted in the significantly higher $(p<0.05)$ average values of penetration resistance $(1.31 \pm 0.44 \mathrm{MPa})$ in the $6-10 \mathrm{~cm}$ layer compared to the uncompacted soil $(0.48 \pm 0.07 \mathrm{MPa})$. The ground contact pressures of 0.103 and $0.154 \mathrm{MPa}$ had no significant effects of penetration resistance in the 6-10 and 11$15 \mathrm{~cm}$ soil layers compared to the uncompacted soil in the same layers.

In the entire $0-15 \mathrm{~cm}$ columns without plants, the average values of penetration resistance were equal to $1.02 \pm 0.64,0.62 \pm 0.41$ and $0.63 \pm 0.36 \mathrm{MPa}$ at the ground contact pressures of $0.051,0.103$ and $0.154 \mathrm{MPa}$, respectively. The differences with penetration resistance of the uncompacted soil $(0.47 \pm 0.11 \mathrm{MPa})$ were significant $(p<0.01)$ only for the ground contact pressure of $0.051 \mathrm{MPa}$. 
In the treatments with plants, the average values of penetration resistance of the $0-5 \mathrm{~cm}$ soil layer were also the most sensitive to the effects of all the applied ground contact pressures. There were significant differences $(p<0.05$ or $p<0.001)$ between the average values of penetration resistance of the uncompacted soil $(0.58 \pm 0.06 \mathrm{MPa})$ and those of the soil compacted by the ground contact pressures of $0.051(1.22 \pm 0.59 \mathrm{MPa})$, $0.103(1.19 \pm 0.38 \mathrm{MPa})$ and $0.154(0.89 \pm 0.17 \mathrm{MPa})$ $\mathrm{MPa}$. In the $0-5 \mathrm{~cm}$ soil layer, the highest penetration resistance $(1.79 \pm 0.37 \mathrm{MPa})$ was recorded at the depth of $4 \mathrm{~cm}$ at the ground contact pressure of $0.051 \mathrm{MPa}$. For some replicates, the value of penetration resistance exceeded the critical value of $2 \mathrm{MPa}$. The ground contact pressure of $0.051 \mathrm{MPa}$ also resulted in significantly higher $(p<0.01)$ average values of penetration resistance $(1.08 \pm 0.26 \mathrm{MPa})$ in the $6-10 \mathrm{~cm}$ soil layer. The ground contact pressures of 0.103 and $0.154 \mathrm{MPa}$ did not cause a significant effect on the mean values of penetration resistance in the $6-10$ and $11-15 \mathrm{~cm}$ layers compared to the uncompacted soil (Figure 2A).

In the whole $0-15 \mathrm{~cm}$ soil columns with plants, the average values of penetration resistance were 0.92 $\pm 0.53,0.73 \pm 0.45$ and $0.59 \pm 0.28 \mathrm{MPa}$ at the ground contact pressures of $0.051,0.103$ and $0.154 \mathrm{MPa}$, respectively. The difference with the uncompacted soil $(0.47 \pm 0.11 \mathrm{MPa})$ was significant $(p<0.01)$ only for the ground contact pressure of $0.051 \mathrm{MPa}$.

At the ground contact pressures of $0.051,0.103$ and $0.154 \mathrm{MPa}$, the weight of dry winter wheat roots in the soil only slightly changed and was $0.61 \pm 0.21$, $0.57 \pm 0.16$ and $0.51 \pm 0.11 \mathrm{~g}$, respectively. In general, roots of winter wheat did not contribute to a recovery of penetration resistance of the soil at the three studied levels of compaction.

The soil moisture content of clayey loam was also a key factor of changes in its penetration resistance under compaction. However, moisture content of the uncompacted soil in the $0-5,6-10$ and $11-15 \mathrm{~cm}$ soil layers was equal to 30.5, 29.4 and $30.0 \%$ (of weight), respectively, and did not affect the depth distribution of penetration resistance.

In the treatments without and with winter wheat growing on the compacted soil, its moisture content decreased with the increasing soil depth. In the treatment without plants, the range of moisture content in the $0-5$, 6-10 and $11-15 \mathrm{~cm}$ soil layers was $13.8-41.0,17.8$ 30.6 and $17.1-29.3 \%$ (of weight), respectively, for all the applied ground contact pressures. The lowest value of moisture content in the $0-5 \mathrm{~cm}$ soil layer could be a reason for its highest penetration resistance at the ground contact pressure of $0.051 \mathrm{MPa}$. At this ground contact pressure, the Pearson correlation coefficients for the relationships between penetration resistance and moisture content in the $0-5,6-10$ and $11-15 \mathrm{~cm}$ soil layers were $-0.85,-0.98$ and -0.97 , respectively.

In the treatments with plants, moisture content in the $0-5,6-10$ and $11-15 \mathrm{~cm}$ soil layers was changing in the ranges of $15.0-38.9,18.2-37.1$ and $19.5-33.9 \%$ (of weight), respectively, for all the applied ground contact pressures. The Pearson correlation coefficients for the relationships between penetration resistance and moisture content in the $0-5,6-10$ and $11-15 \mathrm{~cm}$ soil layers were $-0.97,-0.91$ and -0.97 , respectively.

Effects of compaction on disturbance and recovery of the water-stable aggregates (WSA) in sandy loam. In the whole $0-15 \mathrm{~cm}$ layer of the uncompacted soil, the mean value of the total amount of WSA was low and equal to $9.7 \pm 1.5 \%$. The ground contact pressures of $0.051,0.103$ and $0.154 \mathrm{MPa}$ caused a significant decrease $(p<0.001)$ in the total amount of WSA to $4.3 \pm 0.2,3.9 \pm$ 0.2 and $4.3 \pm 0.5 \%$, respectively. In relative terms, these values were equal to 44,40 and $44 \%$ of the total amount of WSA in the uncompacted soil.

The winter wheat growing contributed to a significant increase $(p<0.001$ to $p<0.05)$ in the total amount of WSA to $7.0 \pm 0.8,7.3 \pm 2.9$ and $5.9 \pm 1.4 \%$ in the soil compacted by the ground contact pressures of $0.051,0.103$ and $0.154 \mathrm{MPa}$, respectively. Considering the total amount of WSA in the uncompacted soil and in the compacted soil without plants, the relative rootinduced recovery of the total amount of WSA was partial and reached 28, 35 and $17 \%$ for the ground contact pressures $0.051,0.103$ and $0.154 \mathrm{MPa}$, respectively.

Our experimental data supported the results of other studies on the positive effects of roots of barley, winter wheat and pea (Pisum sativum subsp. arvense) on the recovery of water-stable aggregation of disturbed soils (Vezzani et al., 2018). The recovery of WSA with a temporal development of winter wheat root system in the soil was not an objective of our research. In our opinion, the recovery of the total amount of WSA in the compacted soil up to their reference values probably has not occurred, because the interaction forces between soil particles or between roots, and particles were weak in the sandy loam at a given amount of roots and at a given soil compaction level (Six et al., 2002; 2004; Moreno-Espíndola et al., 2007). According to results of our previous experiment (Balashov, Bazzoffi, 2003), the recovery capacity of the winter wheat root system was sufficient for the formation of WSA in the sandy loam and clayey loam compacted by the ground contact pressures of 0.051 and 0.103 but not $0.154 \mathrm{MPa}$.

The size fractions of WSA of the sandy loam showed a different degree of their resistance and recovery after compaction by the ground contact pressures of $0.051,0.103$ and $0.154 \mathrm{MPa}$ (Figure 3). Among the WSA of the uncompacted soil, the size fraction of $0.25-0.5 \mathrm{~mm}$ had the highest $(7.25 \pm 1.24 \%)$ and of $5.66-9.51 \mathrm{~mm}-$ the lowest $(0.08 \pm 0.12 \%)$ content of the total amount of WSA. The size fractions of $0.25-0.5,0.5-1.0$ and $2.8-5.66 \mathrm{~mm}$ were most sensitive to the compaction and demonstrated a significant decrease (from $p<0.001$ to $p<0.05)$ after application of the three applied ground contact pressures. In relative terms, the decrease in the amount of these WSA size fractions in the compacted soil was 38-43, 40-47 and 26-38\% for the ground contact pressures of $0.051,0.103$ and $0.154 \mathrm{MPa}$, respectively.

As mentioned above, the mean weight of dry roots was $1.11 \pm 0.74,0.84 \pm 0.51$ and $0.44 \pm 0.13 \mathrm{~g}$ in the soil compacted by the ground contact pressures of $0.051,0.103$ and $0.154 \mathrm{MPa}$, respectively. Data of our experiment showed that the highest root concentration $(1.11 \pm 0.74 \mathrm{~g})$ had caused a significant $(p<0.05,<0.01$ and $<0.001)$ partial and full recovery of the amounts of all the five WSA size fractions in compacted soil compared to the uncompacted soil (Figure 3A). The roots with the dry weight of $0.84 \pm 0.51 \mathrm{~g}$ significantly $(p<0.05)$ contributed to the partial and full recovery of amounts of only four $(0.25-0.5,0.5-1.0,1.0-2.8$ and $5.66-9.51 \mathrm{~mm})$ size WSA fractions at the ground contact pressure of $0.103 \mathrm{MPa}$. The roots of winter wheat with the lowest dry weight of $0.44 \pm 0.13 \mathrm{~g}$ contributed only to partial recovery of two WSA size fractions with the lowest $(0.25-0.5$ and $0.5-1.0 \mathrm{~mm})$ diameters at the ground 

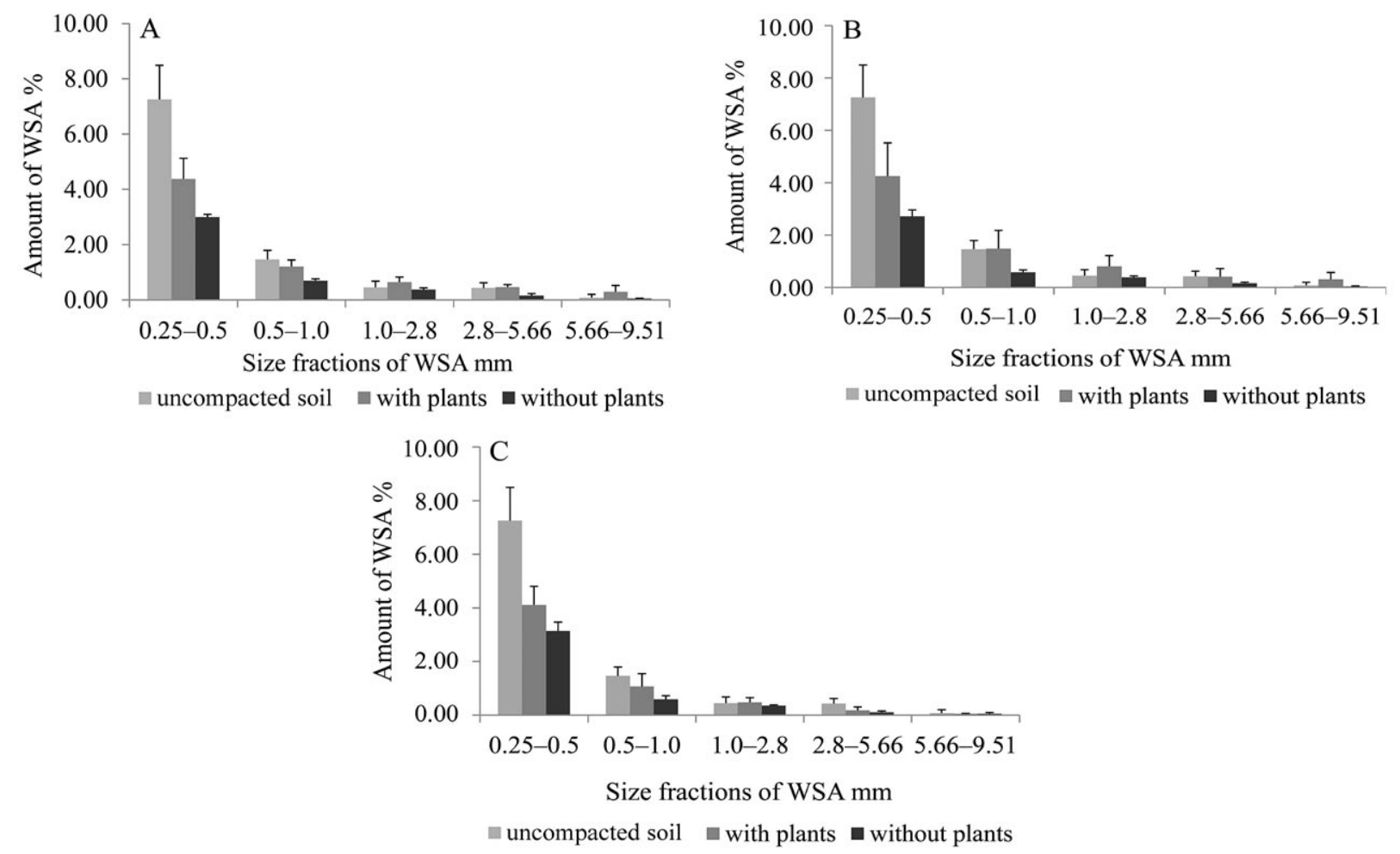

Note. Bars show the $95 \%$ confidence intervals for the means.

Figure 3. The amount of the water-stable aggregates (WSA) size fractions in uncompacted soil and compacted sandy loam at the ground contact pressures of 0.051 (A), 0.103 (B) and 0.154 (C) MPa with and without winter wheat

contact pressure of $0.154 \mathrm{MPa}$. The mean dry weight of winter wheat shoots also decreased with the increasing ground contact pressures and was equal to $2.69 \pm 0.88$, $2.03 \pm 0.40$ and $1.38 \pm 0.08 \mathrm{~g}$ for the ground contact pressures of $0.051,0.103$ and $0.154 \mathrm{MPa}$, respectively.

The described results showed that the significant and partial root-induced recovery of all the five WSA size fractions in sandy loam could be reached only at the ground contact pressure of $0.051 \mathrm{MPa}$, which maintained the most intensive growth of winter wheat roots. However, the recovery of all the five WSA fractions did not result in the full recovery of the total amount of WSA up to its reference values.

Effects of compaction on disturbance and recovery of the water-stable aggregates (WSA) in clayley loam. The mean of the total amount of WSA in the entire $0-15 \mathrm{~cm}$ layer in the uncompacted soil was equal to 14.8 $\pm 1.3 \%$. According to the results of the one-way ANOVA, in the compacted soils without plants, application of the ground contact pressures of $0.051,0.103$ and $0.154 \mathrm{MPa}$ resulted in a significant decrease $(p<0.001)$ of the total amount of WSA to $9.0 \pm 1.2,8.6 \pm 1.1$ and $8.1 \pm 0.7 \%$, respectively. In relative terms, these numbers were equal to 60,58 and $55 \%$ of the total amount of WSA in the uncompacted soil. The WSA of clayey loam showed a higher resistance to all the applied ground contact pressures than the WSA of the sandy loam because of higher content of clay particles with stronger binding forces than sand particles in WSA (de Andrade Bonetti et al., 2017).

In the treatments with plants, the total amount of WSA was $15.2 \pm 0.9,10.5 \pm 1.9$ and $9.0 \pm 0.6 \%$ at the ground contact pressures of $0.051,0.103$ and $0.154 \mathrm{MPa}$, respectively. The mean values of the total amount of WSA in the soil with plants significantly $(p<0.001$, $p<0.05$ and $p<0.05$ ) exceeded those in the soil without plants at the ground contact pressures of $0.051,0.103$ and $0.154 \mathrm{MPa}$, respectively. After applying the ground contact pressure of $0.051 \mathrm{MPa}$, the relative recovery of the total amount of WSA by the winter wheat roots was full and equal to $103 \%$ of the total amount of WSA in the uncompacted soil. At the ground contact pressures of 0.103 and $0.154 \mathrm{MPa}$, winter wheat roots contributed to the WSA recovery only partially, by $13 \%$ and $6 \%$. The ground contact pressures of 0.103 and $0.154 \mathrm{MPa}$ were probably too high for the root-induced full recovery of the WSA after compaction of clayey loam.

At the ground contact pressures of $0.051,0.103$ and $0.154 \mathrm{MPa}$, the dry weights of winter wheat roots were slightly decreasing with the increasing pressure and was $0.61 \pm 0.21,0.57 \pm 0.16$ and $0.51 \pm 0.11 \mathrm{~g}$, respectively, and, therefore, the roots did not play a key role in the recovery of the total amount of WSA after compaction of clayey loam compared to clay particles. The mean weight of the dry winter wheat shoots also decreased with the increasing ground contact pressure and was $1.59 \pm 0.17,1.40 \pm 0.28$ and $1.14 \pm 0.20 \mathrm{~g}$ for the ground contact pressures of $0.051,0.103$ and $0.154 \mathrm{MPa}$, respectively.

The distribution of the WSA size fractions in the compacted clayey loam by the three applied ground contact pressures in the treatments without and with winter wheat plants are presented in Figure 4.

In the treatments without plants, the ground contact pressures resulted in a significant $(p<0.05)$ decrease of the amount of most of the WSA size fractions with the exception of $0.25-0.5$ and $1.0-2.8 \mathrm{~mm}$ fractions at the ground contact pressure of $0.051 \mathrm{MPa}$, of $0.25-0.5$ and $2.8-5.66 \mathrm{~mm}$ fractions at the ground contact pressure of $0.103 \mathrm{MPa}$ and of $1.0-2.8 \mathrm{~mm}$ fraction at the ground contact pressure of $0.154 \mathrm{MPa}$ compared to the same WSA size fractions of the uncompacted soil. These WSA 

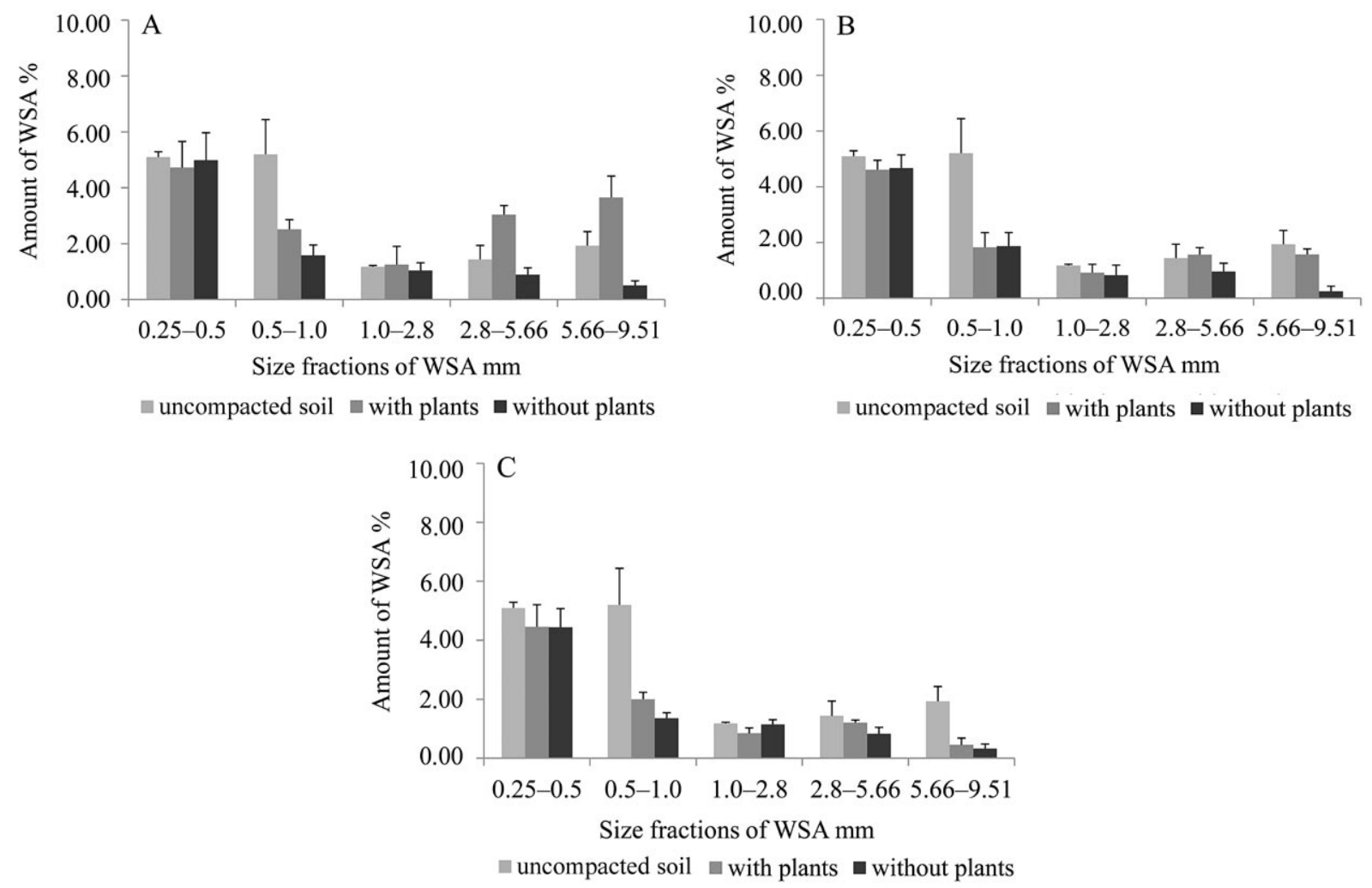

Note. Bars show the $95 \%$ confidence intervals for the means.

Figure 4. The amount of the water-stable aggregates (WSA) size fractions in uncompacted soil and compacted clayey loam at the ground contact pressures of 0.051 (A), 0.103 (B) and 0.154 (C) MPa with and without winter wheat

size fractions can be considered as the most resistant to all the applied ground contact pressures. In relative terms, the amounts of all WSA size fractions at the three studied levels of compaction were in the ranges of 26-98, 13-92 and $17-97 \%$ of the amounts of corresponding WSA size fractions of the uncompacted soil.

In the treatments with plants, the roots contributed to the full recovery of the amount of such WSA size fractions as 1.0-2.8, 2.8-5.66 and 5.66-9.51 $\mathrm{mm}$ in the soil with the ground contact pressure of $0.051 \mathrm{MPa}$ (Figure 4A). The amount of these WSA size fractions even exceeded that of the uncompacted soil. In the soil compacted by the ground contact pressure of $0.103 \mathrm{MPa}$, the roots contributed to full recovery of WSA only in $2.8-5.66 \mathrm{~mm}$ size fraction and contributed to a partial recovery of WSA in 1.0-2.8 and 5.66-9.51 mm the size fractions compared to the same size fractions of WSA in the uncompacted and compacted soils (Figure 4B). The roots were unable to support the full recovery of any WSA size fraction in the treatment of the ground contact pressure of $0.154 \mathrm{MPa}$ (Figure 4C). Nevertheless, at this ground contact pressure the roots contributed to a significant increase $(p<0.05)$ in the amounts of $0.5-1.0$ and 2.8-5.66 mm size fractions of WSA compared to the same fractions of the compacted soil without plants.

The results of the current experiment showed that the roots of winter wheat could quite significantly contribute to recovery of WSA size fractions in the compacted soil. However, these positive and even significant root-induced changes in the amounts of separate size fractions of WSA were insufficient for the full recovery of total amount of WSA after applying the ground contact pressures of 0.103 and $0.154 \mathrm{MPa}$ on the clayey loam.

\section{Conclusions}

1. Winter wheat roots contributed to the recovery of the soil bulk density in the clayey loam by $1.4,3.8$ and $4.9 \%$, but caused the increase in the bulk density of the sandy loam by $6.2,5.1$ and $1.8 \%$ at the ground contact pressures of $0.051,0.103$ and $0.154 \mathrm{MPa}$, respectively.

2. Winter wheat roots did not significantly influence the recovery of penetration resistance of the sandy loam or the clayey loam compacted by the ground contact pressures of $0.051,0.103$ and $0.154 \mathrm{MPa}$.

3. Winter wheat roots contributed to the recovery of the total amount of water-stable aggregates (WSA) in the sandy loam by 28,35 and $17 \%$ and in the clayey loam by 103,13 and $6 \%$ at the ground contact pressures of $0.051,0.103$ and $0.154 \mathrm{MPa}$, respectively.

\section{Acknowledgements}

Dr. E. Balashov carried out these joint studies partly with the financial support of the Outreach Fellowship Programme of the National Research Council (Italy) and partly in the framework of the research plan of the Agrophysical Research Institute (St. Petersburg, Russia).

The authors are greatly indebted to Dr. A. Rocchini for his assistance with soil sampling during the experiments and to the two reviewers of this paper for their useful comments and improvements that helped to make the paper much better. 


\section{References}

Arthur E., Schjønning P., Moldrup P., de Jonge L. W. 2012. Soil resistance and resilience to mechanical stresses for three differently managed sandy loam soils. Geoderma, 173-174: 50-60. https://doi.org/10.1016/j.geoderma.2012.01.007

Atkinson J. A., Hawkesford M. J., Whalley W. R., Zhou H., Mooney S. J. 2020. Soil strength influences wheat root interactions with soil macropores. Plant, Cell and Environment. 43 (1): 235-245 https://doi.org/10.1111/pce.13659

Balashov E., Bazzoffi P. 2003. Aggregate water stability of sandy and clayey loam soils differently compacted with and without wheat plants. International Agrophysics, 17 (4): 151-155.

Bartzen B. T., Hoelscher G. L., Ribeiro L. L. O., Seidel E. P. 2019. How the soil resistance to penetration affects the development of agricultural crops? Journal of Experimental Agriculture International, 30 (5): 1-17. https://doi.org/10.9734/JEAI/2019/46589

Batey T. 2009. Soil compaction and soil management - a review. Soil Use and Management, 25 (4): 335-345. https://doi.org/10.1111/j.1475-2743.2009.00236.x

Bengough A. G., McKenzie B. M., Hallett P. D., Valentine T. A. 2011. Root elongation, water stress, and mechanical impedance: a review of limiting stresses and beneficial root tin traits. Journal of Exnerimental Botany, 62 (1): 59-68. https://doi.org/10.1093/jxb/erq350

Bianchi A. 1995. Durum wheat crop in Italy. Di Fonzo N et al. (eds). Durum wheat quality in the Mediterranean region. Options Méditerranéennes: Série A. Séminaires Méditerranéens, 22: 105-108. https://om.ciheam.org/om/ pdf/a22/95605358.pdf

Bodner G., Leitner D., Kaul H P. 2014. Coarse and fine root plants affect pore size distributions differently. Plant and Soil. 380 (1): 133-151. https://doi.org/10.1007/s11104-014-2079-8

Carrara M., Castrignanò A., Comparetti A., Febo P., Orlando S 2007. Mapping of penetrometer resistance in relation to tractor traffic using multivariate geostatistics. Geoderma, 142 (3-4): 294-307. https://doi.org/10.1016/j.geoderma.2007.08.020

Carrizo M. E., Alesso C. A., Cosentino D., Imhoff S. 2015. Aggregation agents and structural stability in soils with different texture and organic carbon contents. Scientia Agricola, 72 (1): 75-82. https://doi.org/10.1590/0103-9016-2014-0026

Chalise K. S., Singh S., Wegner B. R., Kumar S., PérezGutiérrez J. D., Osborne S. L., Nleya T., Guzman J., Rohila J. S. 2019. Cover crops and returning residue impact on soil organic carbon, bulk density, penetration resistance, water retention, infiltration, and soybean yield. Agronomy Journal, 111 (1): 99-108. https://doi.org/10.2134/agronj2018.03.0213

Chimungu J. G., Loades K. W., Lynch J. P. 2015. Root anatomical phenes predict root penetration ability and biomechanical properties in maize (Zea mays). Journal of Exnerimental Botany, 66 (11): 3151-3162. https://doi.org/10.1093/jxb/erv121

Chomczyńska M., Soldatov V., Wasag H., Turski M. 2016. Effect of ion exchange substrate on grass root development and cohesion of sandy soil. International Agronhysics, 30 (3): 293-300. https://doi.org/10.1515/intag-2015-0095

Clark L. J., Whalley W. R., Barraclough P. B. 2003. How do roots nenetrate strong soil? Plant and Soil, 101: 93-104. https://doi.org/10.1023/A:1026140122848

de Andrade Bonetti J., Anghinoni I., de Moraes M. T., Fink J. R. 2017. Resilience of soils with different texture, mineralogy and organic matter under long-term conservation systems. Soil and Tillage Research. 174: 104-112. https://doi.org/10.1016/j.still.2017.06.008

de Moraes M. T., Debiasi H., Franchini J. C., Mastroberti A. A., Levien R., Leitner D., Schnepf A. 2020. Soil compaction impacts soybean root growth in an Oxisol from subtropical Brazil. Soil and Tillage Research. 200: 104611. https://doi.org/10.1016/j.still.2020.104611
Denef K., Six J. 2005. Contributions of incorporated residue and living roots to aggregate-associated and microbial carbon in two soils with different clay mineralogy. European Journal of Soil Science, 57 (6): 774-786. https://doi.org/10.1111/j.1365-2389.2004.00682.x

Ferreira C. J. B., Tormena C. A., Severiano E. D. C., Zotarelli L., Betioli Júnior E. 2020. Soil compaction influences soil physical quality and soybean yield under long-term notillage. Archives of Agronomy and Soil Science. 67 (3): 383-396. https://doi.org/10.1080/03650340.2020.1733535

Gould I. J., Quinton J. N., Weigelt A., De Deyn G. B., Bardgett R. D. 2016. Plant diversity and root traits benefit physical properties key to soil function in grasslands. Ecologv Letters. 19 (9): 1140-1149. https://doi.org/10.1111/ele.12652

Hargreaves P. R., Baker K. L., Graceson A., Bonnett S., Ball B. C., Cloy J. M. 2019. Soil compaction effects on grassland silage yields and soil structure under different levels of compaction over three years. European Journal of Agronomy. 109: 12591. https://doi.org/10.1016/j.eja.2019.125916

Helliwell J. R., Sturrock C. J., Miller A. J., Whalley W. R., Mooney S. J. 2019. The role of plant species and soil condition in the structural development of the rhizosphere. Plant, Cell and Environment, 42 (6): 1974-1986. https://doi.org/10.1111/pce.13529

Holthusen D., Brandt A. A., Reichert J. M., Horn R., Fleige H., Zink A. 2018. Soil functions and in situ stress distribution in subtropical soils as affected by land use, vehicle type, tire inflation pressure and plant residue removal. Soil and Tillage Research, 184: 78-92. https://doi.org/10.1016/j.still.2018.07.009

Koebernick N., Daly K. R., Keyes S. D., George T. S., Brown L. K., Raffan A., Cooper L. J., Naveed M., Bengough A. G., Sinclair I., Hallett P. D., Roose T. 2017. High-resolution synchrotron imaging shows that root hairs influence rhizosphere soil structure formation. New Phytologist, 216 (1): 124-135 https://doi.org/10.1111/nph.14705

Koebernick N., Daly K. R., Keyes, S. D., Bengough A. G., Brown L. K., Cooper L. J., George T.S., Hallett P. D., Naveed M., Raffan A., Roose T. 2019. Imaging microstructure of the barley rhizosphere: particle packing and root hair influences. New Phytologist. 221 (4): 1878-1889. https://doi.org/10.1111/nph.1551

Martins M. R., Corá J. E., Jorge R. F., Marcelo A. V. 2009. Crop type influences soil aggregation and organic matter under no-tillage. Soil and Tillage Research, 104: 22-29. https://doi.org/10.1016/j.still.2008.11.003

Moreno-Espíndola I. P., Rivera-Becerril F., de Jesús FerraraGuerrero M., De León-González F. 2007. Role of root-hairs and hyphae in adhesion of sand particles. Soil Biology and Biochemistrv. 39 (10): 2520-2526. https://doi.org/10.1016/j.soilbio.2007.04.021

Mujdeci M., Isildar A. A., Uygur V., Alaboz P., Unlu H., Senol H. 2017. Cooperative effects of field traffic and organic matter treatments on some compaction-related soil properties. Solid Earth. 8 (1): 189-198. https://doi.org/10.5194/se-8-189-2017

Oleghe E., Naveed M., Baggs E. M., Hallett P. D. 2017. Plant exudates improve the mechanical conditions for root penetration through compacted soils. Plant and Soil. 421 (1): 19-30. https://doi.org/10.1007/s11104-017-3424-5

Pagliai M., Marsili A., Servadio P., Vignozzi N., Pellegrini S. 2003. Changes in some physical properties of a clay soil in Central Italy following the passage of rubber tracked and wheeled tractors of medium power. Soil and Tillage Research. 73 (1-2): 119-129. https://doi.org/10.1016/S0167-1987(03)00105-3

Rizaldi T., Susanto E., Napitupulu R. P. 2020. Soil compaction study due to 4 wheel tractor track in PTPN II Kulmpang sugar cane plantation. Journal of Physics: Conference Series. 1542: 012048. https://doi.org/10.1088/1742-6596/1542/1/012048 
Seehusen T., Riggert R., Fleige H., Horn R., Riley H. 2019. Soil compaction and stress propagation after different wheeling intensities on a silt soil in South-East Norway. Acta Agriculturae Scandinavica, Section B: Soil and Plant Science. 69 (4): $343-355$ https://doi.org/10.1080/09064710.2019.1576762

Six J., Feller C., Denef K., Ogle S, de Moraes Sa J. C., Albrecht A. 2002. Soil organic matter, biota and aggregation in temperate and tropical soils - effects of no-tillage. Agronomie. 22 (7-8): 755-775. https://doi.org/10.1051/agro:2002043

Six J., Bossuyt H., Degryze S., Denef K. 2004. A history of research on the link between (micro) aggregates, soil biota, and soil organic matter dynamics. Soil and Tillage Research, 79 (1): 7-31. https://doi.org/10.1016/j.still.2004.03.008

Steponavičienè V., Bogužas V., Sinkevičienė A., Skinulienė L., Sinkevičius A. 2020. Soil physical state as influenced by long-term reduced tillage, no-tillage and straw management. Zemdirbvste-Agriculture. 107 (3): 195-202. https://doi.org/10.13080/z-a.2020.107.025

Stumpf L., dos Anjos Leal O., Pauletto E. A., Pinto L. F. S., Reis D. A., Pinto M. A. B., Tuchtenhagen I. K. 2018. Tensile strength and organic matter fractions in aggregates of a grass-covered mined soil under early stage recovery. Soil and Tillage Research, 176: 69-76.

\section{https://doi.org/10.1016/j.still.2017.11.006}

Torri D., Regüés D., Pellegrini S., Bazzoffi P. 1999. Withinstorm soil surface dynamics and erosive effects of rainstorms. Catena. 38 (2): 131-150. https://doi.org/10.1016/S0341-8162(99)00059-4

Valboa G., Lagomarsino A., Brandi G., Agnelli A. E., Simoncini S., Papini R., Vignozzi N., Pellegrini S. 2015. Long-term variations in soil organic matter under different tillage intensities. Soil and Tillage Research, 154: 126-135. https://doi.org/10.1016/j.still.2015.06.017

Vergani C., Graf F. 2016. Soil permeability, aggregate stability and root growth: a pot experiment from a soil bioengineering nersnective. Ecohvdrologv. 9 (5): 830-842. https://doi.org/10.1002/eco.1686

Vezzani F. M., Anderson C., Meenken E., Gillespie R., Peterson M., Beare M. H. 2018. The importance of plants to development and maintenance of soil structure, microbial communities and ecosystem functions. Soil and Tillage Research, 175: 139-149. https://doi.org/10.1016/j.still.2017.09.002

WRB. 2014. World reference base for soil resources. World Soil Resources Reports No. 106. FAO, 189 p.

\title{
Žieminių kviečių šaknų poveikis dirvožemio tankio, kietumo ir vandenyje patvarių trupinèliụ atkūrimui smẻlingo priemolio Eutric Cambisol ir molingo priemolio Vertic Cambisol po suslègimo
}

\author{
E. Balashov ${ }^{1}$, S. Pellegrini ${ }^{2}$, P. Bazzoffi ${ }^{2}$ \\ ${ }^{1}$ Rusijos agrofizikinių tyrimų institutas \\ ${ }^{2}$ Italijos žemès ūkio tyrimų ir ekonomikos Žemès ūkio ir aplinkos taryba
}

\begin{abstract}
Santrauka
Eksperimento tikslai: (1) ịvertinti paviršiaus suslėgimo 0,051, 0,103 ir 0,154 MPa poveikị smèlingo priemolio Eutric Cambisol bei molingo priemolio Vertic Cambisol fizikinèms savybèms ir (2) ịvertinti žieminių kviečiu šaknu poveiką suslègtų dirvožemių fizikinių savybių atkūrimui. Vegetaciniame eksperimente žieminiai kviečiai (Triticum aestivum L.) buvo auginti 49 dienas iki $\mathrm{BBCH} 10$ augimo tarpsnio. Dirvožemio kontaktinis suslegimas buvo atliktas rankiniu būdu valdomu hidrauliniu kompresoriumi su manometru. Eksperimento kontrolinis variantas vegetaciniai indai su nesuslègtu dirvožemiu ir be augalų. Dirvožemio tankis, kietumas, suminis vandenyje patvariụ trupinèlių kiekis, jų dydžio frakcijos ir sausų šaknų masè eksperimento pabaigoje buvo nustatyti abiejų dirvožemių $0-15 \mathrm{~cm}$ sluoksnyje.

Nustatyta, kad paveikus visais kontaktiniais slègiais abiejų dirvožemių be augalų $0-15 \mathrm{~cm}$ sluoksnyje tankio vidutinès vertès buvo žymiai didesnès, palyginti su kontroliniu variantu. Dirvožemio kontaktiniam suslègimui esant 0,051 , 0,103 ir $0,154 \mathrm{MPa}$, žieminių kviečių šaknys molingame priemolyje lèmé tankio vidutinių verčiu $1,4,3,8$ ir $4,9 \%$ sumažèjimą, o smèlingame priemolyje šios vertès padidèjo atitinkamai 6,2, 5,1 ir 1,8 \%. Dirvožemio kontaktinis suslègimas sąlygojo reikšmingą viršutinio $0-5 \mathrm{~cm}$ sluoksnio kietumo padidèjimą molingame ir smèlingame priemoliuose be augalų, palyginti su kontroliniu variantu. Šaknys neturejjo ịtakos reikšmingam abiejų dirvožemiu vidutiniu kietumo dydžiu pokyčiui esant trims suslègimo lygiams. Abiejų dirvožemių suminis vandenyje patvarių trupinèlių kiekis reikšmingai sumažèjo paviršių paveikus visais tirtais kontaktinio suslègimo lygiais, palyginus su nesuslègtu dirvožemiu. Žieminių kviečiu šaknys turèjo didžiausią ịtaką daliniam suminiam vandenyje patvarių trupinèlių kiekio atkūrimui abiejuose suslègtuose dirvožemiuose, palyginus su kontroliniu variantu.
\end{abstract}

Reikšminiai žodžiai: atkūrimas, dirvožemis, dirvožemio kietumas, dirvožemio tūrinis tankis, suslègimas, vandenyje patvarūs trupinèliai, žieminių kviečių šaknys. 